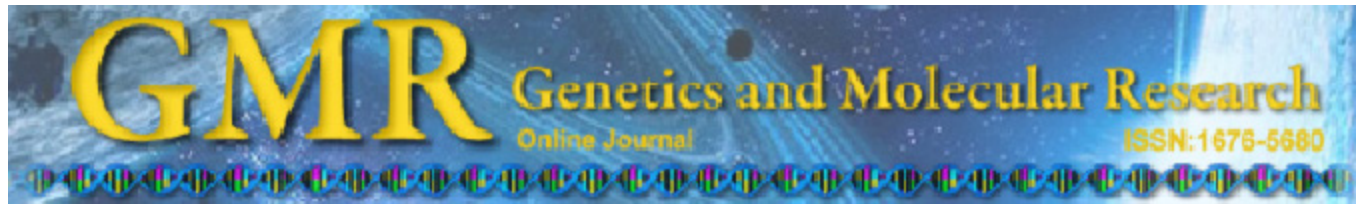

\title{
Soybean rust resistance sources and inheritance in the common bean (Phaseolus vulgaris L.)
}

\author{
T.L.P.O. Souza ${ }^{1}$, S.N. Dessaune ${ }^{2}$, M.A. Moreira $^{3 \dagger}$ and E.G. Barros ${ }^{4}$ \\ ${ }^{1}$ Embrapa Arroz e Feijão, Santo Antônio de Goiás, GO, Brasil \\ ${ }^{2}$ Embrapa Cerrados, Planaltina, DF, Brasil \\ ${ }^{3}$ Instituto de Biotecnologia Aplicada à Agropecuária, \\ Universidade Federal de Viçosa, Viçosa, MG, Brasil \\ ${ }^{4}$ Programa de Pós-Graduação em Ciências Genômicas e Biotecnologia, \\ Universidade Católica de Brasília, Brasília, DF, Brasil
}

$\dagger$ In memoriam

Corresponding author: T.L.P.O. Souza

E-mail: thiago.souza@embrapa.br

Genet. Mol. Res. 13 (3): 5626-5636 (2014)

Received October 25, 2013

Accepted February 24, 2014

Published July 25, 2014

DOI http://dx.doi.org/10.4238/2014.July.25.18

\begin{abstract}
Soybean rust (SBR), caused by the fungus Phakopsora pachyrhizi, has been reported in common bean (Phaseolus vulgaris L.) cultivars and elite lines that were infected under controlled and natural field conditions in South Africa, the United States, Argentina, and Brazil. Although SBR is currently not a top priority problem for the common bean crop, many bean breeders are concerned about this disease because of the high severity and virulence diversity of $P$. pachyrhizi and its broad host range. In this study, a set of $44 P$. vulgaris genotypes were tested for resistance to $P$. pachyrhizi; these genotypes included resistance sources to several fungal common bean diseases, carioca-, black- and red-seeded Brazilian cultivars, and elite lines that were developed by the main common bean breeding programs in Brazil. Twenty-four SBR resistance sources were identified. They presented the
\end{abstract}


reddish-brown (RB) lesion type, characterizing resistance reactions. In addition to the RB lesion type, the PI181996 line presented the lowest disease severity mean score, considering its associated standard error value. For this reason, it was crossed with susceptible lines to study the inheritance of resistance. The results support the hypothesis that resistance to SBR in PI181996 is monogenic and dominant. We propose that this SBR resistance gene, the first to be identified and characterized in common bean, might be designated as $P k p-1$.

Key words: Disease resistance; Inheritance study;

Phakopsora pachyrhizi; Plant breeding; Resistance gene

\section{INTRODUCTION}

Soybean rust (SBR), caused by the highly variable fungus Phakopsora pachyrhizi H. Sydow and P. Sydow, is reported as a major disease that limits soybean (Glycine max L.) production in Asia (Hartman et al., 1992) and in the Americas. Since the first detection of $P$. pachyrhizi incidence associated with rust epidemics on the American continents, the pathogen has moved swiftly from one country to another. SBR was first reported in Paraguay and Brazil in 2001, in Argentina in 2002, in Bolivia in 2003, in Uruguay and in the USA in 2004, and in Mexico in 2005 (Ivancovich, 2005; Pivonia et al., 2005; Schneider et al., 2005; Yorinori et al., 2005). In Brazil, SBR was first found and disseminated in the south-central areas. In May 2001, it was detected in the west region of the State of Paraná. In the 2001-2002 crop season, the disease was already found on all soybean fields in Paraná and in some areas of the states of Rio Grande do Sul, Goiás, Mato Grosso, and Mato Grosso do Sul. Yield losses due to soybean rust ranged from 30 to $75 \%$ (Yorinori et al., 2005). Currently, SBR is endemic in almost all Brazilian soybean-growing areas, and all soybean commercial cultivars are susceptible to $P$. pachyrhizi.

Control measures for SBR include cultural practices (crop rotation, soil incorporation of infected soybean debris, planting within recommended dates, etc.), growing tolerant cultivars when available, and timely spraying of fungicides (Hartman et al., 1992). Compared to chemical control, the most used method to date, the use of resistant cultivars not only is harmless to the environment but also is an economically sound strategy. However, the great severity and variability of the pathogen prevent the efficient control of $P$. pachyrhizi by plant resistance and the identification of effective resistance sources in soybean.

The host range of $P$. pachyrhizi is broad, affecting over 90 species, including some economically important crops (Rytter et al., 1984; Ono et al., 1992). Among them is the common bean (Phaseolus vulgaris L.), the food legume most used for direct human consumption worldwide. The virulence of $P$. pachyrhizi has been reported on $P$. vulgaris cultivars that were grown under field and controlled conditions and tested by natural and artificial pathogen inoculations. The first study on the virulence of $P$. pachyrhizi in common bean lines inoculated under controlled conditions was performed by Stavely et al. (1985). More recently, SBR was reported on common bean lines grown under natural field conditions in South Africa, Brazil, and the USA in 2005, and in Argentina in 2006 (DuPreez et al., 2005; Nunes-Junior et al., 2005; Lynch et al., 2006; Pastor-Corrales et al., 2006, 2007; Ivancovich et al., 2007). 
In the research developed by Miles et al. (2007), common bean lines resistant to bean rust caused by Uromyces appendiculatus F. Strauss (syn. U. phaseoli G. Winter) were tested against six isolates of $P$. pachyrhizi from Asia, Africa, and South America. Resistance to all six isolates was identified. As previously reported by Stavely et al. (1985), when lesion sizes and spore production were compared between susceptible soybean and common bean lines that were inoculated with virulent $P$. pachyrhizi isolates, the common bean lines presented smaller lesions and fewer spores. According to Stavely et al. (1985), when these same rust symptoms were compared in susceptible common bean genotypes that were inoculated with P. pachyrhizi and $U$. appendiculatus, the SBR pathogen caused smaller lesions with fewer spores than the bean rust pathogen. It was concluded that $P$. pachyrhizi was not a threat to common bean production unlike $U$. appendiculatus. The decreased severity of SBR on P. vulgaris compared to G. max lines using natural inoculation assays under field conditions was also reported by DuPreez et al. (2005), Nunes-Junior et al. (2005), Lynch et al. (2006), Pastor-Corrales et al. (2006, 2007), and Ivancovich et al. (2007). Nevertheless, because of the virulence diversity of P. pachyrhizi, in addition to its broad host range and great dispersal capacity, many bean breeders are concerned about SBR because it can also become a serious problem for the common bean crop in endemic areas.

A similar phenomenon was previously reported for the common bean growing system. The angular leaf spot, which is caused by the fungus Pseudocercospora griseola (Sacc.) Crous and $U$. Braun, was considered to be one of the least important diseases for the bean crop until approximately 20 years ago. However, angular leaf spot is now one of the most destructive fungal diseases affecting common bean production in Brazil and other tropical and subtropical growing areas of the world. In Brazil, yield losses caused by P. griseola may reach between 70 and $100 \%$ (de Jesus et al., 2001).

Based on the reported information, the identification and use of SBR resistance sources in P. vulgaris are being considered as an important strategy to prevent potential concerns of the common bean breeding programs focused on disease resistance. In addition, considering the current possibilities presented by modern biotechnology tools, this effort may also lead to the development of soybean cultivars harboring common bean genes presenting effective resistance to $P$. pachyrhizi.

The main goal of this study was to identify SBR resistance sources among common bean genotypes from the P. vulgaris Active Germplasm Bank of Instituto de Biotecnologia Aplicada à Agropecuária/Universidade Federal de Viçosa (BIOAGRO/UFV), Viçosa, MG, Brazil. Aiming to understand the mode of genetic inheritance of plant resistance in the $P$. pachyrhizi-P. vulgaris pathosystem, we also determined the genetic control of SBR resistance in the common bean line PI181996, the main resistance source identified in this study.

\section{MATERIAL AND METHODS}

\section{Plant material}

The common bean genotypes that were screened for SBR resistance in this research include resistance sources to common bean diseases such as rust, anthracnose, and angular leaf spot; Brazilian commercial cultivars with carioca, black, and red genetic backgrounds; 
and advanced lines that were developed by the main common bean breeding programs in Brazil. Seeds from cultivars IAPAR 14, IAPAR 16, and IAPAR 57 were provided by Instituto Agronômico do Paraná (IAPAR), Londrina, PR, Brazil. Seeds from all other common bean lines were supplied by BIOAGRO/UFV.

Soybean cultivars CAC-1 and Cristalina were used as susceptible controls in the SBR resistance screening because they are highly susceptible to $P$. pachyrhizi under field conditions in Brazil. Soybean lines harboring four previously identified single dominant resistance genes to the SBR pathogen were also included as controls in the inoculation assays: PI200492 (Rpp1 gene); PI547878 (Rpp2 gene), a line derived from Willians (susceptible) and PI230970 (Rpp2 gene); PI462312 (Rpp3 gene); and PI459025 (Rpp4 gene). Seeds from all soybean lines were provided by $\mathrm{BIOAGRO/UFV.}$

In order to increase vigor and the germination capacity, seeds from all common bean and soybean lines were multiplied under greenhouse conditions before the disease screening tests. Ten plants from each genotype were inoculated with the pathogen.

\section{P. pachyrhizi inoculums}

The initial inoculum of the P. pachyrhizi isolate that was used in this study was obtained from soybean cultivar CAC-1 plants that were naturally infected under field conditions in the UFV Experimental Stations located in Coimbra, MG, Brazil. The rust spores were periodically multiplied on cultivar $\mathrm{CAC}-1$ to increase the inoculum and maintain its virulence. Because the isolate did not originate from a single spore lesion, it is possible that it represents a mixture of more than one pathotype. Therefore, all multiplications of the isolate and screening procedures were monitored for the appearance of mixed lesions or highly contrasting reaction degrees on plants of the same common bean or soybean genotype. No mixed lesion types were observed in our greenhouse inoculations. In addition, high variation was not observed in the standard error values associated with the mean scores of disease reaction for the different common bean and soybean genotypes that were screened in this study. A similar strategy to obtain inoculum was used by Garcia et al. (2008) to study the genetics of host resistance in the P. pachyrhizi-G. max pathosystem.

Although $P$. pachyrhizi does not grow in artificial culture because it is an obligate parasite, viable spores can be preserved under artificial conditions. In this study, dry spores in plastic or glass tubes were successfully maintained under dark conditions at $-80^{\circ} \mathrm{C}$ or in liquid nitrogen.

Genomic DNA of frozen spores obtained from the isolate used in this study was used for polymerase chain reaction (PCR) analysis with specific primers that were designed to amplify internal transcribed spacer (ITS) regions of P. pachyrhizi (Asian SBR) and Phakopsora meibomiae (Arthur) (American SBR) (Frederick et al., 2002). Differentiation between Asian SBR and American SBR symptoms by visual evaluation only is not efficient (Ono et al., 1992). Fungal DNA extraction and PCR conditions were as described by Frederick et al. (2002). The primers used for the P. pachyrhizispecific assay were Ppm1 (5'-GCAGAATTCAGTGAATCATCAAG-3') and Ppa2 (5'-GCAACACTCAAAATCCAACAAT-3'), and those for the P. meibomiae-specific assay were Ppm1 and Pme2 (5'-CTCAAACAGGTGTACCTTTTGG-3'). Each DNA amplification assay consisted of an initial denaturation step at $94^{\circ} \mathrm{C}$ for $3 \mathrm{~min} ; 30$ cycles at $94^{\circ} \mathrm{C}$ for 1 
min, $57^{\circ} \mathrm{C}$ for $1 \mathrm{~min}$, and $72^{\circ} \mathrm{C}$ for $1 \mathrm{~min}$ and $30 \mathrm{~s}$; and a final step at $72^{\circ} \mathrm{C}$ for $7 \mathrm{~min}$. The electrophoresis analyses were performed on $3.0 \%$ agarose gels containing $0.2 \mu \mathrm{g} / \mathrm{mL}$ ethidium bromide and immersed in a $1 \mathrm{X}$ sodium boric acid (SB) buffer (10 mM sodium hydroxide, $\mathrm{pH}$ adjusted to 8.5 with boric acid). The DNA template controls of P. pachyrhizi and P. meibomiae were provided by Embrapa Soja, Londrina, PR, Brazil.

\section{Inoculation and disease screening}

The primary leaves and the first trifolium of all plants were inoculated about 15 days after emergence under greenhouse conditions $\left(20^{\circ} \pm 5^{\circ} \mathrm{C}\right)$. Prior to inoculation, spores were removed from storage conditions $\left(-80^{\circ} \mathrm{C}\right)$, heat shocked at $40^{\circ} \mathrm{C}$ for $10 \mathrm{~min}$, and hydrated by incubation in a small plastic weigh boat over water for $24 \mathrm{~h}$. The inoculum concentration was $3.0 \times 10^{5}$ P. pachyrhizi spores $/ \mathrm{mL}$ distilled water containing $0.05 \%$ Tween-20 (v/v). The inoculum was sprayed on both leaf surfaces using a manual atomizer (De Vilbiss No. 15, USA) powered by an electric compressor. After inoculation, the plants were transferred to a mist chamber $\left(20^{\circ} \pm 1^{\circ} \mathrm{C}\right.$ and relative humidity $\left.>95 \%\right)$, where they were kept for $48 \mathrm{~h}$ under a $12-\mathrm{h}$ light regime. After this period, the plants were transferred to a greenhouse $\left(20^{\circ} \pm 5^{\circ} \mathrm{C}\right)$, where they were kept until symptom evaluation.

Disease symptoms were evaluated 20 days after the inoculations. The disease severity was evaluated based on a 1-to-5 scale described by Miles et al. (2007). This scale is based on lesion density, where 1 = no visible lesions, 2 = few scattered lesions present, 3 = moderate number of lesions on at least part of the leaf, $4=$ abundant number of lesions on at least part of the leaf, and 5 = prolific lesion development over most of the leaf. When different plants of the same genotype were evaluated, the mean scores of severity were calculated for each genotype. The presence of the tan-colored (TAN) lesion type or reddish-brown (RB) lesion type was also recorded. The TAN lesion type was considered to be a susceptible reaction, whereas the RB lesion type was considered to be resistant (major-gene resistance). Rust lesions on both surfaces of the inoculated leaves were determined visually by at least two independent evaluators.

\section{Crosses and genetic analysis of $F_{1}, F_{2}$, and $F_{3}$ populations}

The inheritance of SBR resistance in the common bean line PI181996 was studied by crossing this resistance source with the susceptible lines US Pinto 111 and Mexico 309. The plants were grown and artificially crossed under greenhouse conditions.

To identify the hybrids, $F_{1}$ plants from the cross PI181996 x US Pinto 111 were analyzed morphologically (flower color). Because PI181996 and Mexico 309 are black-seeded beans with similar morphological traits including flower color, the $\mathrm{F}_{1}$ plants derived from crosses between them were analyzed with molecular markers as proposed by Alzate-Marin et al. (1996). Because Mexico 309 was used as the female parent, the presence of a PCR product that was present only in PI181996 confirmed that the $\mathrm{F}_{1}$ plant was indeed a hybrid. Plant DNA samples were extracted according to Doyle and Doyle (1990). DNA amplification by the random amplification of polymorphic DNA-PCR technique was accomplished according to Alzate-Marin et al. (1996), and the electrophoresis analyses were done on 1.2\% agarose gels containing $0.2 \mu \mathrm{g} / \mathrm{mL}$ ethidium bromide that were immersed in $1 \mathrm{X} \mathrm{SB}$ buffer. All $\mathrm{F}_{1}$ plants selected were used to obtain the $\mathrm{F}_{2}$ and $\mathrm{F}_{3}$ populations. 
Plants from the $\mathrm{F}_{2}$ and $\mathrm{F}_{3}$ populations, soybean control cultivars CAC-1 and Cristalina, and the parental common bean lines were inoculated with P. pachyrhizi and screened for SBR reaction. The ratio of resistant (RB) and susceptible (TAN) reactions that was observed in the segregating population was tested for goodness-of-fit to theoretical ratios with the chisquare $\left(\chi^{2}\right)$ test.

\section{RESULTS}

\section{Molecular detection test for Phakopsora spp}

PCR analysis using the genomic DNA of spores from the inoculum that was used in this study and ITS region-specific primers for P. pachyrhizi and P. meibomiae detection, which were previously reported by Frederick et al. (2002), was efficiently accomplished. The results are shown in Figure 1. The amplification of PCR products with only the P. pachyrhizi-specific primers confirmed that the inoculum that was used for SBR resistance screening was indeed from P. pachyrhizi.
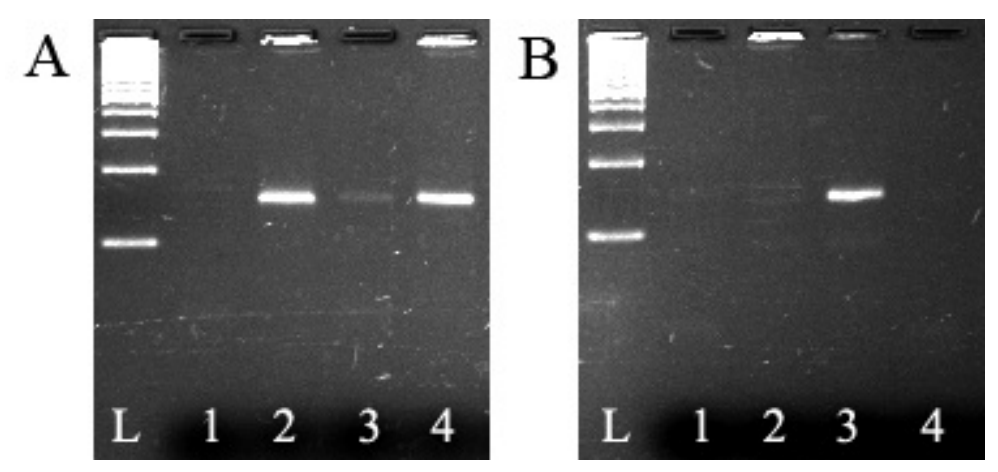

Figure 1. Molecular detection test for Phakopsora spp. Electrophoretic analysis of amplification products obtained with Phakopsora pachyrhizi- (A) and Phakopsora meibomiae-specific (B) primers (Frederick et al., 2002) on a 3.0\% agarose gel. Lanes are as follows: Lane $L=$ size marker (100-bp DNA ladder); lane $1=$ no DNA template control; lane $2=$. pachyrhizi DNA control; lane $3=$ P. meibomiae DNA control; lane $4=$ genomic DNA of spores obtained from the P. pachyrhizi inoculum used in this study. Polymerase chain reaction products between 100 and $200 \mathrm{bp}$ are present in lanes $2 \mathrm{~A}, 4 \mathrm{~A}$, and $3 \mathrm{~B}$.

\section{Reaction of common bean lines to SBR}

Of the 44 common bean genotypes that were tested against the SBR pathogen, 24 were considered to be resistant because they showed the RB lesion type (Table 1). None of the common bean genotypes presented an immune reaction to P. pachyrhizi. However, three resistant genotypes, PI181996, Pérola, and Redlands Pioneer, were considered to be promising sources for SBR resistance. They presented RB reactions and mean scores of disease severity of $2.25 \pm 0.26,2.20 \pm 0.41$, and $2.20 \pm 0.35$, respectively. On the other hand, 20 P. vulgarissusceptible genotypes were identified. Among them, 13 should be highlighted: AND 277, Cornell 49-242, CSW 643, Diamante Negro, Dorado, Mexico 309, Mexico 54, Ouro Vermelho, 
PI260418, Pinto Olathe, Rudá, US Pinto 111, and Vermelhinho. In addition to showing the TAN lesion type, these genotypes presented mean scores of disease severity that were equal to or greater than 4.50 (Table 1). Even though they showed the RB lesion type, and for this reason were classified as resistant genotypes, G 2333, SEL 1308, and TU presented high mean scores of severity ( $4.15 \pm 0.24,4.60 \pm 0.32$, and $4.55 \pm 0.44$, respectively) (Table 1$)$.

Table 1. Reactions of common bean genotypes and soybean control lines to soybean rust (Phakopsora pachyrhizi) expressed as lesion types and mean scores of disease severity with their respective standard error (SE) values.

\begin{tabular}{|c|c|c|c|c|c|c|c|}
\hline \multirow[t]{2}{*}{ Common bean genotype } & \multirow[t]{2}{*}{ Lesion type $^{1}$} & \multicolumn{2}{|c|}{ Disease severity $^{2}$} & \multirow[t]{2}{*}{ Common bean genotype } & \multirow[t]{2}{*}{ Lesion type } & \multicolumn{2}{|c|}{ Disease severity } \\
\hline & & Mean & SE & & & Mean & SE \\
\hline AB 136 & $\mathrm{RB}$ & 3.75 & 0.35 & Ouro vermelho & TAN & 4.55 & 0.37 \\
\hline AND 277 & TAN & 4.55 & 0.37 & P-33-5-1 & $\mathrm{RB}$ & 3.00 & 0.00 \\
\hline Aurora & TAN & 4.15 & 0.34 & P-49-8-2 & $\mathrm{RB}$ & 3.65 & 0.24 \\
\hline BAT 332 & $\mathrm{RB}$ & 3.20 & 0.35 & Pérola & $\mathrm{RB}$ & 2.20 & 0.41 \\
\hline Brow Beauty & $\mathrm{RB}$ & 3.00 & 0.00 & PI181996 & $\mathrm{RB}$ & 2.25 & 0.26 \\
\hline $\mathrm{CNC}$ & $\mathrm{RB}$ & 3.75 & 0.26 & PI260418 & TAN & 4.50 & 0.33 \\
\hline Cornell 49-242 & TAN & 4.65 & 0.34 & Pinto Olathe & TAN & 4.70 & 0.42 \\
\hline CSW 643 & TAN & 4.65 & 0.34 & R-127-4-13 & $\mathrm{RB}$ & 2.85 & 0.24 \\
\hline Diamante Negro & TAN & 4.55 & 0.37 & R-127-10-14 & $\mathrm{RB}$ & 2.95 & 0.37 \\
\hline Dorado & TAN & 4.65 & 0.41 & R-97-13-5 & $\mathrm{RB}$ & 3.80 & 0.26 \\
\hline G 2333 & $\mathrm{RB}$ & 4.15 & 0.24 & R-97-13-6 & $\mathrm{RB}$ & 2.95 & 0.16 \\
\hline Golden Gate Wax & TAN & 4.20 & 0.35 & Redlands Pioneer & $\mathrm{RB}$ & 2.20 & 0.35 \\
\hline IAPAR 14 & $\mathrm{RB}$ & 2.95 & 0.44 & Rudá & TAN & 4.65 & 0.34 \\
\hline IAPAR 16 & $\mathrm{RB}$ & 2.95 & 0.16 & SEL 1308 & $\mathrm{RB}$ & 4.60 & 0.32 \\
\hline IAPAR 57 & $\mathrm{RB}$ & 3.00 & 0.33 & BRSMG Talismã & TAN & 4.00 & 0.24 \\
\hline Jalo EEP 558 & $\mathrm{RB}$ & 2.75 & 0.42 & TO & $\mathrm{RB}$ & 3.80 & 0.26 \\
\hline MAR-2 & TAN & 4.15 & 0.24 & $\mathrm{TU}$ & $\mathrm{RB}$ & 4.55 & 0.44 \\
\hline Mexico 235 & TAN & 4.15 & 0.34 & US Pinto 111 & TAN & 4.75 & 0.26 \\
\hline Mexico 309 & TAN & 4.55 & 0.16 & BRS Valente & $\mathrm{RB}$ & 2.75 & 0.35 \\
\hline Mexico 54 & TAN & 4.65 & 0.41 & Vermelhinho & TAN & 4.60 & 0.46 \\
\hline Montcalm & TAN & 4.40 & 0.39 & Vermelho 2157 & TAN & 4.20 & 0.35 \\
\hline Ouro Negro & $\mathrm{RB}$ & 3.35 & 0.24 & BRSMG Pioneiro & $\mathrm{RB}$ & 3.00 & 0.33 \\
\hline \multirow[t]{2}{*}{ Soybean control line } & Lesion type & \multicolumn{2}{|c|}{ Disease severity } & \multirow[t]{2}{*}{ Soybean control line } & \multirow[t]{2}{*}{ Lesion type } & \multicolumn{2}{|c|}{ Disease severity } \\
\hline & & Mean & SE & & & Mean & SE \\
\hline CAC-1 & TAN & 5.00 & 0.00 & PI547878 (Rpp2) & $\mathrm{RB}$ & 5.00 & 0.00 \\
\hline Cristalina & TAN & 4.95 & 0.16 & PI462312 (Rpp3) & TAN & 4.25 & 0.16 \\
\hline PI200492 (Rppl) & TAN & 4.75 & 0.20 & PI459025 (Rpp4) & $\mathrm{RB}$ & 4.58 & 0.13 \\
\hline
\end{tabular}

${ }^{1}$ Tan-colored (TAN) or reddish-brown (RB) lesion types; the TAN lesion type indicates a susceptible reaction, whereas the RB lesion type indicates a resistance reaction (major-gene reaction). ${ }^{2}$ Mean scores of disease severity based on a 1-to-5 scale described by Miles et al. (2007), where $1=$ no visible lesions and $5=$ prolific lesion development over most of the leaf; mean scores of severity were obtained by evaluating 10 plants from each common bean genotype or soybean control line.

All soybean cultivars showed high mean scores of disease severity, including the lines harboring the resistance genes Rpp1, Rpp2, Rpp3, and Rpp4 (Table 1). However, PI547878 (Rpp2 gene) and PI459025 (Rpp4 gene) presented the RB lesion type.

As previously reported by Stavely et al. (1985) and Miles et al. (2007), the soybean cultivars presented greater lesion sizes and spore production than the susceptible common bean genotypes (data not shown).

Although the inoculum that was used for the disease screening tests did not originate from a single pustule, no mixed lesion types or highly contrasting reaction degrees were observed on plants from the same soybean or common bean genotype. This could be verified by analyzing the standard error values that were associated with the mean scores of disease reaction (Table 1). 


\section{Inheritance study}

Two hundred forty-six $\mathrm{F}_{2}$ plants derived from the cross US Pinto 111 x PI181996 and $46 \mathrm{~F}_{2}$ plants from the cross Mexico 309 x PI181996 were tested against the fungus $P$. pachyrhizi. The segregation for resistance to SBR in both $\mathrm{F}_{2}$ populations fit a 3 resistant (RB) to 1 susceptible (TAN) ratio (3R_: $1 \mathrm{rr})$ with $\chi^{2}$ values of 0.0487 and 0.0289 , and probability (P) values of 82.52 and $86.48 \%$, respectively (Table 2 ).

Table 2. Inheritance of soybean rust (Phakopsora pachyrhizi) resistance in the common bean line PI181996.
\begin{tabular}{lcccccc}
\hline Cross & Population & No. of plants tested & Expected ratio $^{1}$ & Observed ratio & Chi-square & P (\%) \\
\hline US Pinto 111 x PI181996 & $\mathrm{F}_{2}$ & 246 & $3(\mathrm{R}): 1(\mathrm{~S})^{2}$ & $183(\mathrm{R}): 63(\mathrm{~S})$ & 0.0487 & 82.52 \\
& $\mathrm{~F}_{3}$ & 107 & $5(\mathrm{R}): 3(\mathrm{~S})^{3}$ & $67(\mathrm{R}): 40(\mathrm{~S})$ & 0.0006 & 98.01 \\
Mexico 309 x PI181996 & $\mathrm{F}_{2}$ & 46 & $3(\mathrm{R}): 1(\mathrm{~S})$ & $34(\mathrm{R}): 12(\mathrm{~S})$ & 0.0289 & 86.48 \\
& $\mathrm{~F}_{3}$ & 162 & $5(\mathrm{R}): 3(\mathrm{~S})$ & $106(\mathrm{R}): 56(\mathrm{~S})$ & 0.5942 & 44.08 \\
\hline
\end{tabular}

${ }^{1} \mathrm{R}=$ resistant (RB lesion type); $\mathrm{S}=$ susceptible (TAN lesion type). ${ }^{2}$ Expected dominant monogenic resistance/ susceptibility segregation in an $\mathrm{F}_{2}$ generation. ${ }^{3}$ Expected dominant monogenic resistance/susceptibility segregation in an $\mathrm{F}_{3}$ generation. ${ }^{4}$ Percent probability from the chi-square $\left(\chi^{2}\right)$ test.

One hundred seven $\mathrm{F}_{3}$ plants from the crosses between US Pinto 111 and PI181996 and $162 \mathrm{~F}_{3}$ plants from the cross Mexico 309 x PI181996 were also inoculated. A 5R_:3rr segregation ratio was observed in the $\mathrm{F}_{3}$ populations with $\chi^{2}$ values of 0.0006 and 0.5942 , and $\mathrm{P}$ values of 98.01 and $44.08 \%$, respectively (Table 2 ).

These results support the hypothesis that resistance to SBR in the common bean line PI181996 is controlled by a single gene with an intra-allelic relationship of complete dominance.

\section{DISCUSSION}

This study was developed to identify SBR resistance sources in P. vulgaris and to understand the inheritance of plant resistance in the P. pachyrhizi-P. vulgaris pathosystem so this resistance can be explored by common bean and soybean breeding programs. Forty-four genotypes from the BIOAGRO/UFV P. vulgaris Active Germplasm Bank were screened with the fungus $P$. pachyrhizi. Three genotypes were selected as promising resistance sources based on their disease reactions-RB lesion types and low mean scores of disease severity considering their respective standard error values: PI181996 (2.25 \pm 0.26$)$, Pérola $(2.20 \pm 0.41)$, and Redlands Pioneer (2.20 \pm 0.35 ) (Table 1). PI181996 was already reported to be resistant to six isolates of P. pachyrhizi from Taiwan, Thailand, Zimbabwe, Paraguay, and Brazil when inoculated under controlled conditions in the USA (Miles et al., 2007). This resistance source also presented no visible SBR symptoms in experiments using natural infection under field conditions in Brazil and South Africa (Nunes-Junior et al., 2005; Pastor-Corrales et al., 2006, 2007).

Because PI181996 presented the RB lesion type and the lowest mean score of disease severity in this study, it was used in inheritance studies to elucidate the genetic control of its resistance to SBR. Crosses were performed between PI181996 and the susceptible lines US Pinto 111 and Mexico 309, which presented the TAN lesion type and mean scores of disease severity of $4.75 \pm 0.26$ and $4.55 \pm 0.16$, respectively. The segregating $F_{2}$ and $F_{3}$ populations were obtained from these two crosses and screened with the pathogen. The results showed that 
SBR resistance in PI181996 was monogenic and dominant (Table 2). For this reason, we propose that this SBR resistance gene, the first to be identified and characterized in common bean, might be designated as $P k p-1$. This proposed gene symbol follows the rules for Gene Symbol Nomenclature established by the Genetics Committee of the Bean Improvement Cooperative (http://bic.css.msu.edu/Genetics.cfm).

This research also verified that in general resistance to $P$. pachyrhizi is not correlated with resistance to other fungal common bean diseases, such as rust, anthracnose, and angular leaf spot. Although some advanced carioca lines presented resistance, it is possible that most bean lines that are now being developed in Brazil will be susceptible to the pathogen because carioca, black, and red cultivars that are currently grown in the country were susceptible (Table 1).

SBR is not yet a serious problem for common bean crops, but the results reported here indicate that studies aiming to identify and explore resistance sources in P. vulgaris may be strategic for the common bean breeding programs in Brazil. Additionally, this effort may also help the development of soybean cultivars with effective resistance to SBR because the resistance genes that were identified in soybean conditioned resistance to a limited set of $P$. pachyrhizi pathotypes, and the resistance was not shown to be durable (Hartman et al., 2005). This would obviously demand the cloning of the gene(s) conferring resistance to SBR in the common bean and its (their) transfer to the soybean genome. The differential response to SBR presented by the P. vulgaris genotypes also suggests that some of them could be used as differential cultivars to classify the fungal physiological races.

The Phakopsora spp molecular detection test confirmed that the spores that were used in our inoculation assays were indeed from P. pachyrhizi (Figure 1). Because we did not use an isolate that originated from a single pustule for the SBR resistance screening, it was possible that the inoculum represented a mixture of many pathotypes, making the disease evaluation process difficult. However, no mixed lesions or highly contrasting reaction degrees were observed on the same soybean or common bean genotypes in the greenhouse inoculations, as shown by the standard error values associated with the mean scores of disease reaction that are presented in Table 1. The results from our inheritance studies also showed that the isolate was efficient to detect the monogenic dominant nature of the resistance to SBR in PI181996 (Table 2). However, we cannot discard the possibility of a gene cluster or complex loci (closely linked genes) governing SBR resistance in this common bean line, which was verified for other bean diseases such as rust and anthracnose (Kelly et al., 2003).

On the basis of the results obtained by Stavely et al. (1985), Miles et al. (2007), and Pastor-Corrales et al. (2007) that indicated the common bean line CNC as a promising resistance source to SBR, Pastor-Corrales and Frederick (2008) analyzed the segregation pattern of resistance to SBR among $241 \mathrm{~F}_{2}$ plants that were derived from crosses between the susceptible lines Mexico 309 and CNC. The results suggested that the SBR resistance in CNC was controlled by the interaction of two genes with complete dominance: one dominant allele of each of the two genes is necessary to produce the resistant phenotype, but any recessive homozygote is epistatic to the other gene. However, once the authors used only a single segregating population in their study, they pointed out that additional assays should be carried out to analyze other segregating generations to confirm these preliminary results.

Currently, fungicide spraying is the main effective method to control SBR worldwide. This strategy increases production costs and exposes the environment to high levels of chemicals. As a first step towards the development of common bean cultivars that are resistant 
to SBR, we identified resistance sources and studied the genetic basis of this resistance in $P$. vulgaris. Currently, we are working to identify molecular markers linked to the SBR resistance gene present in PI181996 ( $P k p-1$ gene) for use in marker-assisted selection.

\section{ACKNOWLEDGMENTS}

Research supported by grants from Conselho Nacional de Desenvolvimento Científico e Tecnológico (CNPq) and Fundação de Amparo à Pesquisa do Estado de Minas Gerais (FAPEMIG), Brazilian Government.

\section{REFERENCES}

Alzate-Marin AL, Baía GS, Martins-Filho S and Paula-Júnior TJ (1996). Use of RAPD-PCR to identify true hybrid plants from crosses between closely related progenitors. Rev. Bras. Genet. 19: 621-623.

de Jesus WC, do Vale FX, Coelho RR, Hau B, et al. (2001). Effects of angular leaf spot and rust on yield loss of Phaseolus vulgaris. Phytopathology 91: 1045-1053.

Doyle JJ and Doyle JL (1990). Isolation of plant DNA from fresh tissue. Focus 12: 13-15.

DuPreez ED, van Rij NC, Lawrance KF and Miles MR (2005). First report of soybean rust (Phakopsora pachyrhizi) on dry beans in South Africa. Plant Dis. 89: 206.

Frederick RD, Snyder CL, Peterson GL and Bonde MR (2002). Polymerase chain reaction assays for the detection and discrimination of the soybean rust pathogens Phakopsora pachyrhizi and P. meibomiae. Phytopathology 92: 217227.

Garcia A, Calvo ES, de Souza Kiihl RA, Harada A, et al. (2008). Molecular mapping of soybean rust (Phakopsora pachyrhizi) resistance genes: discovery of a novel locus and alleles. Theor. Appl. Genet. 117: 545-553.

Hartman GL, Saadaoui EM, Tschanz AT and Scientific Eds (1992). Annotated Bibliography of Soybean Rust (Phakopsora pachyrhizi Sydow). In: AVRDC Library Bibliography Series Asian Vegetable Research and Development Center, Tropical Vegetable Information Service, Taipei, 4-1.

Hartman GL, Miles MR and Frederick RD (2005). Breeding for resistance to soybean rust. Plant Dis. 89: 664-666.

Ivancovich AJ (2005). Soybean rust in Argentina. Plant Dis. 89: 667-668.

Ivancovich AJ, Botta G, Rivadaneira M and Saieg E (2007). First report of soybean rust caused by Phakopsora pachyrhizi on Phaseolus spp. in Argentina. Plant Dis. 91: 111.

Kelly JD, Gepts P, Miklas PN and Coyne DP (2003). Tagging and mapping of genes and QTL and molecular markerassisted selection for traits of economic importance in bean and cowpea. Field Crops Res. 82: 135-154.

Lynch TN, Marois JJ, Wright DL and Harmon PF (2006). First report of soybean rust caused by Phakopsora pachyrhizi on Phaseolus spp. in the United States. Plant Dis. 90: 970.

Miles MR, Pastor-Corrales MA, Hartman GL and Frederick RD (2007). Differential response of common bean cultivars to Phakopsora pachyrhizi. Plant Dis. 91: 698-704.

Nunes-Junior J, Campos HD, Sartorato A and del Peloso MJ (2005). Ferrugem Asiática da Soja em Cultivares de Feijoeiro Comum. VIII Congresso Nacional de Pesquisa de Feijão. Embrapa Arroz e Feijão, Goiânia, 466-469.

Ono Y, Buriticá P and Hennen JF (2002). Delimitation of Phakopsora, Physopella and Cerotelium and their species on Leguminosae. Mycol. Res. 96: 825-850.

Pastor-Corrales MA and Frederick RD (2008). Resistance to the soybean rust pathogen (Phakopsora pachyrhizi) in common bean cultivar CNC. Annu. Rep. Bean Improv. Coop. 51: 20-21.

Pastor-Corrales MA, Liebenberg MM, Sartorato A and Arraes-Pereira PA (2006). Reaction of common bean cultivars to the Asian soybean rust pathogen, Phakopsora pachyrhizi, under field conditions in South Africa and Brazil. Annu. Rep. Bean Improv. Coop. 49: 31-32.

Pastor-Corrales MA, Sartorato A, Liebenberg MM and del Peloso MJ (2007). Evaluation of common bean cultivars from the United States for their reaction to soybean rust under field conditions in Brazil and South Africa. Annu. Rep. Bean Improv. Coop. 50: 123-124.

Pivonia S, Yang XB and Pan Z (2005). Assessment of epidemic potential of soybean rust in the United States. Plant Dis. 89: 678-682.

Rytter JL, Dowler WM and Bromfield KR (1984). Additional alternative hosts of Phakopsora pachyrhizi, causal agent of 
soybean rust. Plant Dis. 68: 818-819.

Schneider RW, Hollier CA, Whitam HK and Palm ME (2005). First report of soybean rust caused by Phakopsora pachyrhizi in the continental United States. Plant Dis. 89: 774.

Stavely JR, Rytter JL and Royer MH (1985). Virulence of the soybean rust pathogen, Phakopsora pachyrhizi on Phaseolus vulgaris cultivars. Annu. Rep. Bean Improv. Coop. 28: 35-36.

Yorinori JT, Paiva WM, Frederick RD and Costamilan LM (2005). Epidemics of soybean rust (Phakopsora pachyrhizi) in Brazil and Paraguay from 2001 to 2003. Plant Dis. 89: 675-677. 